\title{
Effect of Temperature Humidity Index on Semen Quality of Bovine Bull
}

\author{
Mridula Sharma*, Bhat Yaqoob, Anoop Singh, Nishant Sharma and Shriya Rawat \\ Department of Veterinary Gynaecology and Obstetrics, College of Veterinary and \\ Animal Sciences, G.B Pant University of Agriculture and Technology, \\ Pantnagar-263145, Uttarakhand, India \\ *Corresponding author
}

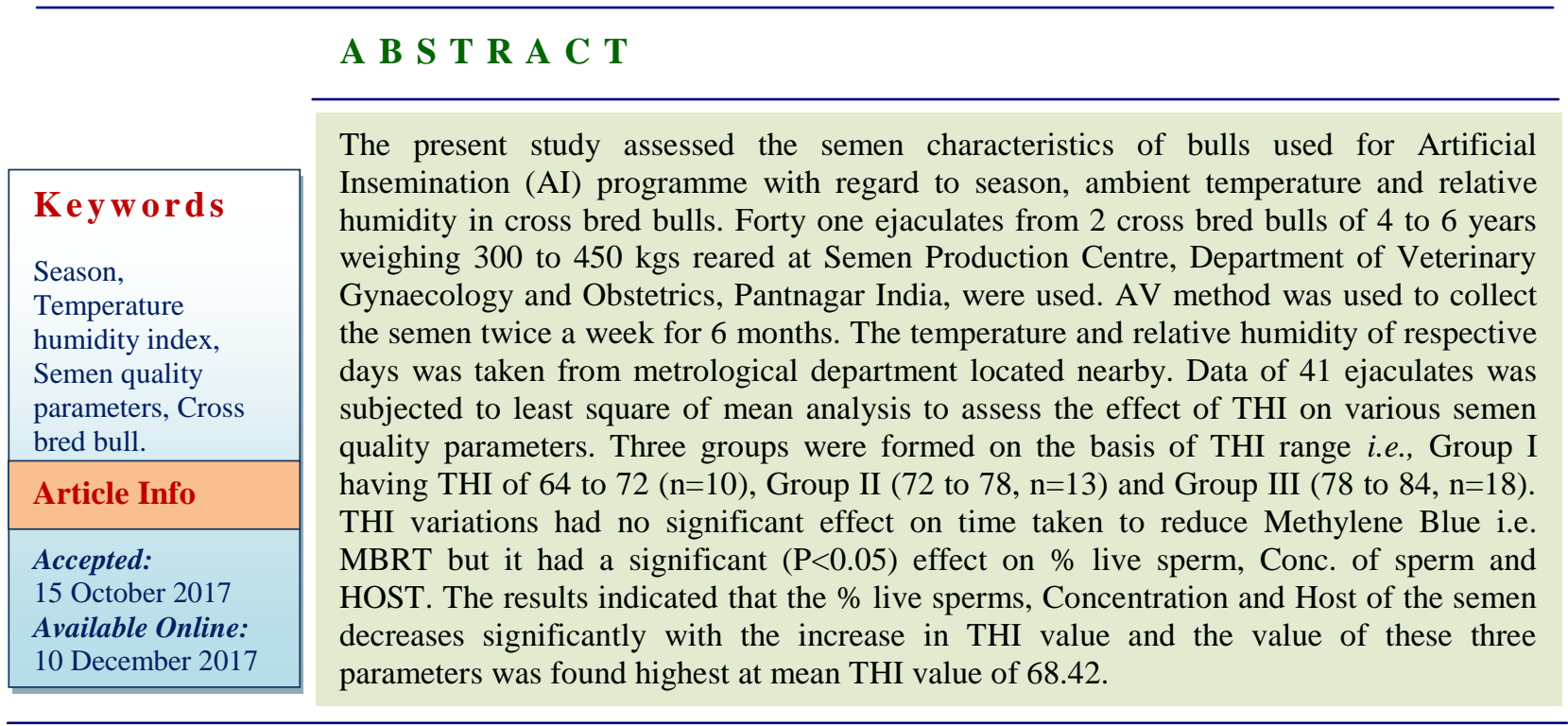

\section{Introduction}

Artificial insemination (AI) of cattle in India is expanding day by day to improve the production potential and genetic merit of our indigenous cows, superior germplasm have been introduced all over India. The success and efficiency of the programme primarily depends on the successful selection of fertile bulls. It is well known that the superior sire can only produce best quality semen. There are many factors that may affect the effectiveness of AI in field condition. The semen characteristics are the major factors that influence conception in cattle and therefore, a determinant of efficiency of reproduction.
Among various factors involved, quality of semen is of important consideration. The bulls used for AI at Pantnagar are mostly crossbred and pure Sahiwal, The adaptability and efficiency of such cross-bred bulls and pure Sahiwal in hot and humid climate as prevailing in Pantnagar are not known. A thorough knowledge of environment related variations particularly temperature and humidity in semen characteristics of these breeds is very important.

Bulls having 50\% exotic blood are used for $\mathrm{AI}$ on indigenous cows. This is because halfbred bulls are found much suitable and treated 
as the best types for the most tropical region for improving indigenous animals (Nagarcenkar, 1982). Breed and season have been shown to have effects on semen production and its quality (Vincent, 1972; Meyerhoeffer et al., 1976; Parkinson, 1987, Sekoni and Gustafsson, 1987). Tomar et al., (1966) reported that there was no seasonal trend in any semen characteristics of Hariana bulls. Seasonal variations in semen production have been observed (Ibrahim et al., 1983; Schwab et al., 1987; Graffer et al., 1988), but specific causes are not understood.

As the seasons of our India vary markedly, special emphasis should be given to the fertility of cross-bred bulls all the year round. Information is not available on the semen characteristics such as volume, colour, density, mass activity, sperm concentration, motility, total number of sperm cells/ejaculates, total number of motile sperm cells /ejaculate, total number of semen doses/ejaculate, HOST, MBRT and postfreezing motility of spermatozoa as influenced by various seasons, ambient temperature and relative humidity. A better and thorough knowledge of the influence of ambient temperature and relative humidity during semen collection on semen characteristics of the AI centres / stations will guide the AI industry to adapt a standard management of bulls to improve semen output. Thus the current study was therefore undertaken to assess the influence of ambient temperature and relative humidity on semen characteristics of the crossbred bull need.

\section{Materials and Methods}

The present experiment was conducted on forty one ejaculate of two cross bred cattle bulls ( 3 to 4 years of age and 300 to $450 \mathrm{~kg}$ body weight) maintained at Semen Production Centre, Department of Veterinary Gynaecology and Obstetrics, Pantnagar,
India. The bulls were healthy, free from diseases, sexually mature, good libido and clinically normal. Three groups were formed on the basis of THI range i.e. Group I having THI of 64 to $72(n=10)$, Group II (72 to 78 , $\mathrm{n}=13$ ) and Group III (78 to $84, \mathrm{n}=18)$. Semen was collected in the morning twice a week from the bull using sterilized artificial vagina (temp $42-45^{\circ} \mathrm{C}$ ), vagina during different months of year i.e. April to October 2015 using dummy bull. Soon after collection the volume of whole ejaculate was measured. Colour and consistency were assessed by direct visualization. The consistency was graded (4-0) as thick creamy, thin creamy, milky, cloudy and clear white. The $\mathrm{pH}$ was measured by Whatmann's $\mathrm{pH}$ indicator paper. Semen tubes were placed in a water bath at $37^{\circ} \mathrm{C}$. Motility of spermatozoa was estimated within 10-15 min from the time of semen collection. Mass motility was determined by placing a small drop of fresh undiluted semen on a glass slide warmed to $34^{\circ} \mathrm{C}$, mounted with cover slip and examined under the low power microscope. A score of 0-5 was given according to the intensity of swirling patterns. Progressive or individual motility was examined in semen diluted with one or two drops of citrate buffer, on a glass slide covered with slip, using high power microscope. The percentage of individual spermatozoa displaying progressive motility across the field was estimated and recorded. The temperature and relative humidity of respective days was taken from metrological department located nearby. The recorded data were subjected to statistical analysis using Least squares means model and ANOVA using LSML-91 software package, Walter Harvey.

\section{Results and Discussion}

Results on various seminal attributes of cross bred bovine bulls during different THI are presented in Table 1. 


\section{Percent live sperms}

The percentage of live sperms in the present study was over $70 \%$, within the acceptable level needed for good fertility (Hancock, 1959; Saacke, 1970) even during hot season.

The results obtained for \% live sperm are summarized in Table 1. The results revealed that there was significant decrease in percentage live sperms in group3 as compared to group 1. The highest and lowest percentage of live sperms was estimated to be $75.33 \pm 0.12$ and $71.53 \pm 1.24 \%$ in Group I and III and clearly indicated that with increase in THI there was a decrease in percent live sperms in ejaculate of cross bred bull.

\section{Conc. of sperm}

Sperm concentration per unit volume of the semen is considered to be one of the most studied and important seminal attribute in relation to variation of semen quality due to temperature and humidity. The results for sperm concentration summarized in Table 1 indicated that sperm concentration decreased significantly with increase in THI.

\section{HOST}

The results of HOST at different THI have been summarized in Table 1 . The results revealed that there was significant difference between the Group I and Group III and Group I and Group II respectively. The percent sperms with coiled and swelled tails in HOST test decreased significantly in Group I compared to Group II.

\section{MBRT (min)}

It is used to study the metabolic activity of spermatozoa. The results obtained for MBRT with change in THI are given in Table 1. The results indicated that there was no significant change in MBRT values with the change in THI.

It has been noted that many factors can influence percent live sperms, concentration, MBRT and Host percent, including animal species, breed, age, nutrition, general health condition, endocrine system function, accommodation, level of exploitation, environmental temperature and relative humidity during semen collection, mean temperature during spermatogenesis and epididymal spermatozoa maturation. As the results obtained in our study, the \% live sperms, Concentration and HOST reacted sperms were decreased significantly with the increase in THI value and the value of these three parameters was found highest in group II. There was significant change in MBRT of semen with the increased range of THI. Chacon et al., (1999) reported that ambient temperature and rainfall were positively correlated with the percentage of abnormal sperm tails, proximal cytoplasmic droplets and percent live sperms in B. Indicus, crossbred, and B. taurus bulls extensively managed in Costa Rica, however, mean ambient temperature (approximately $31{ }^{\circ} \mathrm{C}$ ) was on higher side. Taylor et al., (1985) reported that sperm production in Holstein bulls (sperm concentration, percent live sperms and total sperm number) was greater during the summer in temperate environments. Higher semen quality in dairy B. taurus bulls during the summer was also reported (Chandler et al., 1985; Soderquist et al., 1996, 1997).

Brito et al., (2003) reported that ambient temperature and humidity did not significantly affect sperm production and semen quality. In a study conducted by Majic et al., the lowest sperm concentration was recorded during summer, when THI index was 65.39, and THI-week index was 67.30. Summer conditions consisting of above 
normal ambient temperature, relative humidity, and solar radiation increase the thermal load on animal and causes significant decrease in production potential and may also be detrimental to health of animal. The detrimental effect of high environmental temperature on semen quality and male fertility may be attributed to the hypothalamo- hypophyseal pathways or to a direct effect of temperature on testicular and epididymal function (Pineda, 2003). Elevated environmental temperature during the summer can increase testicular temperatures, metabolic rate and oxygen requirements (Gadea et al., 2004). If intensified metabolism is not followed by enhanced blood flow, testicle tissue becomes hypoxic, which results in excessive ROS production and lipid peroxidation, oxidative stress and decline in spermatozoa motility (Gadea et al., 2004; Nichi et al., 2006). In another study by Mandal et al., (2000) and Ravimurugan et al., (2003) in Murrah bulls sperm concentration per $\mathrm{ml}(\mathrm{SPC})$ varied significantly $(\mathrm{P}<0.01)$ among seasons being maximum during winter when THI is on lower side followed by rainy and summer season where as Prajapati (1995) and Dhami et al., (1998) obtained highest value during rainy season; however, in Egyptian buffalo bulls Oloufa et al., (1959) observed its highest value during spring. On the contrary, Zafar et al., (1988) in Nili-Ravi buffalo bulls; Bhosrekar et al., (1992a) in Murrah; Bhosrekar et al., (1992b) in Surti and Koonjaenak et al., (2007) in Swamp buffalo obtained no significant seasonal variation in sperm concentration.

Table.1 Results on various seminal attributes of cross bred bovine bulls during different THI

\begin{tabular}{|l|l|l|l|}
\hline Parameters & Group I $(\mathbf{n}=\mathbf{1 0})$ & Group II $(\mathbf{n}=13)$ & Group III(n=18) \\
\hline \% live sperm & $75.33 \pm 0.12^{\mathrm{b}}$ & $73.53 \pm 0.47^{\mathrm{ab}}$ & $71.53 \pm 1.24^{\mathrm{a}}$ \\
\hline $\begin{array}{l}\text { Conc. of sperm } \\
\text { (million/ml) }\end{array}$ & $765.53 \pm 2.11^{\mathrm{c}}$ & $733.33 \pm 3.6^{\mathrm{b}}$ & $703.33 \pm 4.3^{\mathrm{a}}$ \\
\hline HOST & & & \\
\hline MBRT(min) & $80.00 \pm 0.00^{\mathrm{b}}$ & $67.80 \pm 0.06^{\mathrm{a}}$ & $66.67 \pm 0.77^{\mathrm{a}}$ \\
\hline
\end{tabular}

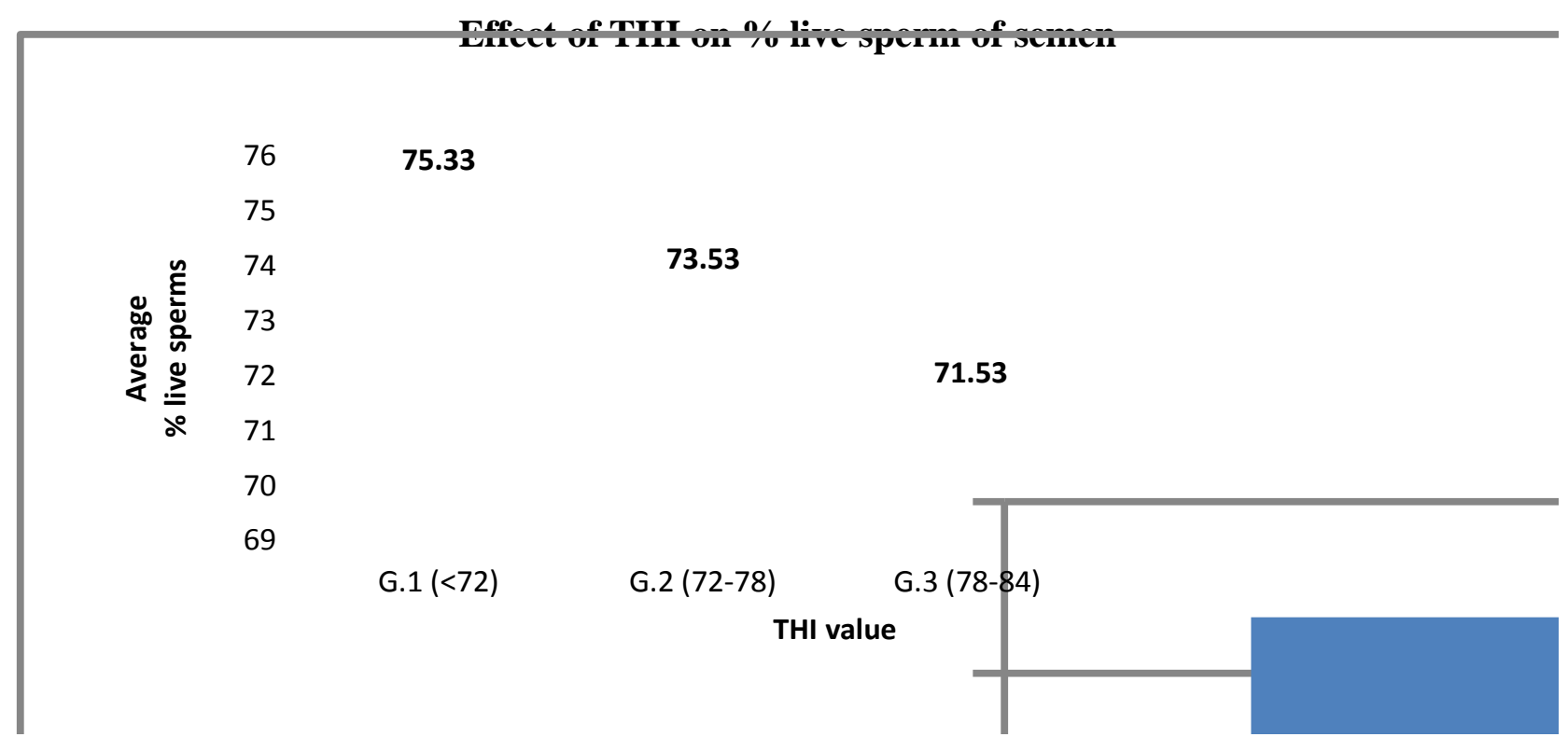



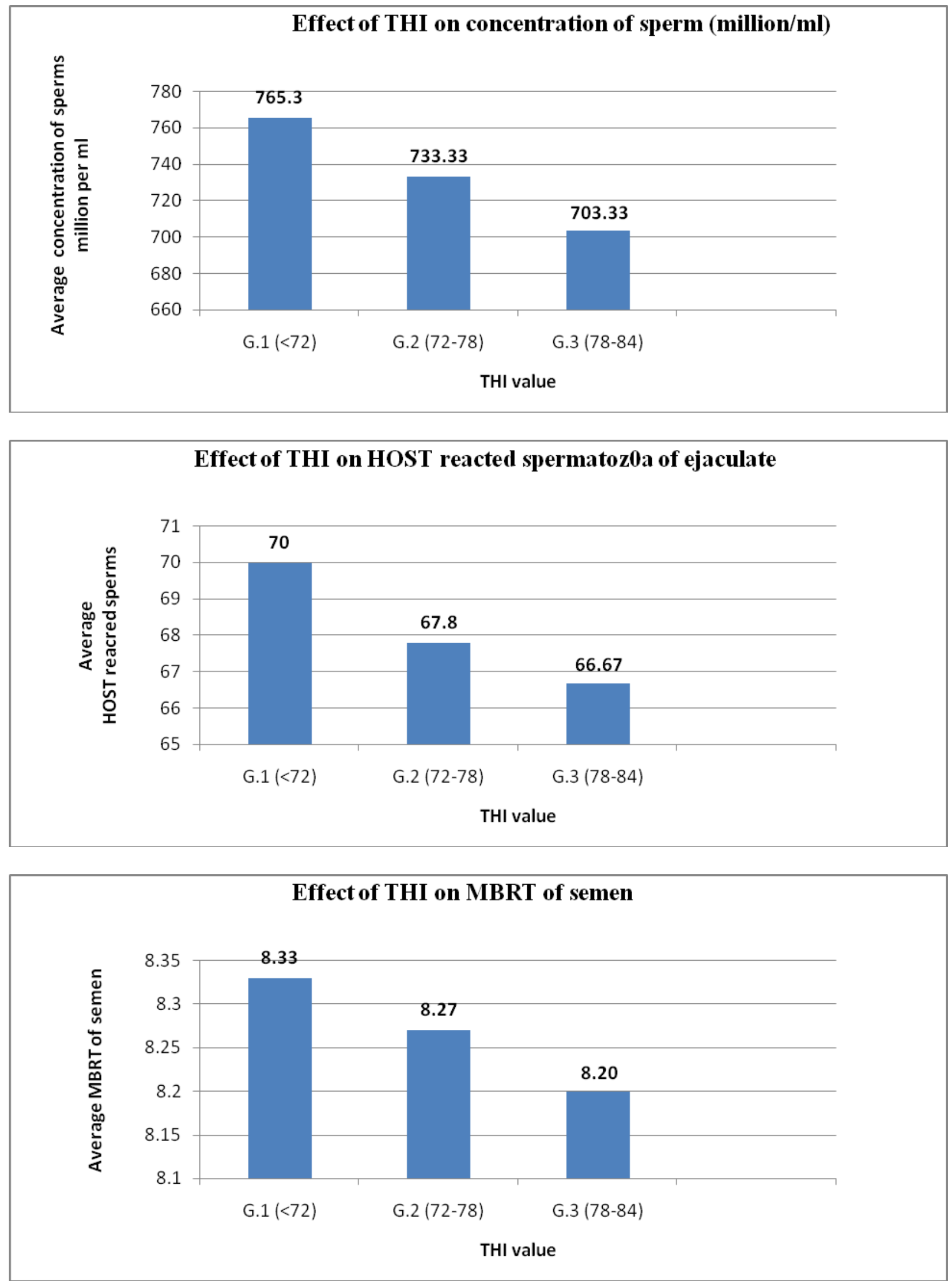
The differences between present and other studies might be due to the result of length of the study period, as well as differences in the age and breed of the bulls. In our finding lower concentration of spermatozoa at higher THI (humid summer) may be due to significant decrease in the feed intake and increase in thermal stress level which results in dead and abnormal spermatozoa. Dead and abnormal spermatozoa are absorbed by leucocytes through phagocytosis (Mann and Mann, 1981).

The increased resorption of abnormal spermatozoa leads to reduction in epididymal sperm reserves (Rao et al., 1980), thus decreasing concentration. This finding support to the conclusion that the spermatozoa produced during summer (high THI) were either intrinsically less active and vigorous at the time of production or that they, though normal at the time of genesis, suffered deterioration at some stage of their passage down the male reproductive tract prior to their release in the ejaculate under sustained impact of a climatically stressful summer environment. Mathevon et al., (1998) reported that Holstein bulls produced more sperm (higher sperm concentration and total sperm number) with greater motility during the winter and the spring (low THI). In the tropics and semi-tropics, sperm production and semen quality decreased during the hot season only in B. taurus and crossbred bulls, but $B$. indicus bulls were not affected (Fields et al., 1979; Kumi-Diaka et al., 1981). However, some authors showed that in Africa, sperm production (ejaculate volume, sperm concentration and total sperm number) and percentage of normal sperm cells decreased during the hot season in B. indicus bulls (Igboeli and Rakha, 1971; Rekwot et al., 1987). In contrast with the present findings, Wildeus and Hammond (1993) did not observe any seasonal effect on sperm production and semen quality in Senepol and
Holstein (B. taurus) bulls in St. Croix, US Virgin Islands.

The bovine spermatozoa have the ability to swell in a hypo osmotic medium (Drevius and Eriksson, 1966; Bredderman and Foote, 1969; Drevius, 1972). The study conducted by Salah et al., confirmed the ability with an average swelling close to that reported for human spermatozoa using the same hypo osmotic solution (Jeyendran et al., 1984). This ability is a sign of normal water transport across the membrane, i.e., is a sign of membrane integrity and normal functional activity. The variations between seasons were not significant with respect to HOST \%. This may be indication of an intrinsic dependent effect not related to seasonal change in temperature and humidity but may be related to breed of bull (Salah et al., 1992). According to Salah et al., 1992 the relationship of THI with host $\%$ of spermatozoa was were not significant. HOST \% was related significantly and positively to the sperm motility. The percentage of dead spermatozoa didn't influence the HOST \% in any season of year. But in man the percentage of swollen spermatozoa in hypo osmotic solution showed higher and significant relationship with both percentages of the sperm motility and the dead spermatozoa which in turn depend upon the ambient temperature and relative humidity of season. The HOST \% of semen is considered as good parameter for semen quality and use for prediction of fertility potential of bulls. Their percentage decreases during hot humid season during which THI is on higher side as compared to spring season. This finding is in agreement with Mishra et al., (2013) and Bhakat et al., (2014) in crossbred bulls. Heat stress enhances the production of ROS (reactive oxygen species) which may disrupt the sperm membrane, as the membrane is highly rich in phospholipids, sterols and polyunsaturated fatty acids, therefore, the sperm membrane is always 
prone to free radical attack. An overloaded oxidative stress has negative effect on spermatogenesis which may lead to damage of sperm membrane and DNA and decreasing the host $\%$ of semen. ROS activity is positively correlated with higher serum Inhibin B in human and it can directly suppress spermatogenesis (Richthoff et al., 2003).

In a study conducted on Karan Fries bulls by Soren et al., (2016) the sperm concentration, total sperm output, HOST $\%$ and total non eosinophilic sperm output were lowered during hot humid when THI is on higher side compared to spring season. Similar findings were also observed by Goswami et al., (1991), Fiaz et al., (2010) and Bhakat et al., (2014) during summer season. Good quality of semen was observed during spring season where the environment temperature was approximately $25^{\circ} \mathrm{C}$.

In our study no significant change was observed in MBRT time which could be because of dependency of MBRT on the metabolic activity of spermatozoa not on the concentration but Hankiewiz et al., (1964) observed strong correlation between dehydrogenase activity of semen, sperm motility, concentration of spermatozoa and live count, showed strong correlation between MBRT and fertility which in turn depends the ambient temperature as temperature influences the metabolic activity of spermatozoa. In a study by Roussel et al., (1963) conducted on dairy bulls to study the Reproductive and physiological responses under varying artificial incandescent illumination, temperature, and humidity conditions. Significant differences $(P<0.01)$ were attained, methylene blue reduction time (modified). However, no significant differences were attained for concentration of spermatozoa. Seasonal variations of semen characteristics were observed for all of the seminal traits except for the wave motion and MBRT in a study conducted on cross bred rams. The data revealed that the optimal performance of the crossbred rams is obtained in late summer and the beginning autumn (Ali et al., 2012).

\section{References}

Bhakat, M., Mohanty, T.K., Gupta, A.K. and Abdullah, M. (2014). Effect of season on semen quality of crossbred (Karan Fries) bulls. Adv. Anim. Vet. Sci., 2(11): 632637.

Bredderman, P.J. and Foote, R.H. (1969) Volume of stressed bull spermatozoa and protoplasmic droplets, and the relationship of cell size to motility and fertility. J. Anim. Sci. IS, 496-501.

Brito L. F., Silva A. E., Rodrigues L. H., Vieira F. V., Deragon L. A. and Kastelic J. P. 2002. Effects of environmental factors, age and genotype on sperm production and semen quality in Bos indicus and Bos taurus AI bulls in Brazil. Anim Reprod Sci., 70:181-90.

Chacon, J., Perez E., Muller, E., Soderquist, L. and Rodriguez-Martinez, H. (1999). Breeding soundness evaluation of extensively managed bulls in Costa Rica. Theriogenology 52, 21-231.

Chandler, J.E., Adkinson, R.W., Hay, G.M., Crain, R.L., 1985. Environmental and genetic sources of variation for seminal quality in mature Holstein bulls. J. Dairy Sci. 68, 1270-1279.

Diarra, M.S., Pare, J.P. and Roy, G. (1997). Genetic and environmental factors affecting semen quality of young Holstein bulls. Can. J. Anim. Sci. 77, 77-85.

Drevius, L.O. and Eriksson, H. (1966) Osmotic swelling of mammalian spermatozoa. Expl Cell Res. 42, 136-156.

Drevius, L.O. (1972). The permeability of bull spermatozoa to water, polyhydric alcohols and univalent anions upon the kinetic activity of spermatozoa and sperm models. J. Reprod. Fert. 28, 41-54. 
Fiaz, M., Usmani, R.H., Abdullah, M. and Ahmad, T. (2010). Evaluation of semen quality of Holstein Friesian and Jersey bulls maintained under subtropical environment. Pak. Vet. J., 30(2): 75-78.

Fields, M.J., Burns, W.C. and Warnick, A.C. (1979). Age, season and breed effects on testicular volume and semen traits in young beef bulls. J. Anim. Sci. 48, 1299 1304.

Gadea J., Sellés E. Marco M. A., Coy P., Matás C. and Romar R. (2004). Decrease in glutathione content in boar sperm after cryopreservation. Effect of the addition of reduced glutathione to the freezing and thawing extenders. Theriogenology; 62:690- 701 .

Godfrey, R.W., Lunstra, D.D., Jenkins, T.G., Berardinelli, J.D., Guthrie, M.J., Neuendorff, D.A., Long, C.R. and Randel, R.D. (1990). Effect of season and location on semen quality and serum concentrations of luteinizing hormone and testosterone in Brahman and Hereford bulls. J. Anim. Sci. 68, 734-749.

Goswami, S.C., Mehta, S.N., Georgie, G.C., Dixit, V.P., Lohan, I.S. and Kaker, M.L. (1991). Effect of meteorological factors and seasons on luteinizing hormone, testosterone and semen of zebu-taurus bulls. Indian J. Anim. Sci., 61(6): 579583.

Graffer, T., Solbu, H. and Filseth, O. 1988. Semen production in artificial insemination bulls in Norway. Theriogenol. 30: 1011-1021.

Hancock, J. 1. (1959). The morphological characteristics of spermatozoa and fertility. Intern. J. Fert. 4:3 47-359.

Hankiewiez, J., K. HanKiewiez, S. Hanus and J. Szafiarski (1964). Enzymologia 28:100

Ibrahim, M.A.R., Rahman, H.A., Toth, B.L. \& Abedin, M. 1983. Effect on season and bacterial contamination on semen quality, freezability, and fertility of Hungarian Simmental artificial insemination bulls. Acta-Vet.-Hungaeca. 31: 81-85.

Igboeli, G. and Rakha, A.M. (1971). Seasonal changes in the ejaculate characteristics of
Angoni (short horn zebu) bulls. J. Anim. Sci. 33, 651-654.

Jeyendran, R. S., Van deer vent, H. H., PerezPelaez, M., Crabo, B. G. and Zaneveld, L. J. D. (1984). Development of an assay to assess the functional integrity of human sperm membrane and its relationship to other semen characteristics. $J$. Reproduction. Fert. 70:219-228.

Kumi-Diaka, J., Nagaratnam, V. and Rwuaan, J.S. (1981). Seasonal and age-related changes in semen quality and testicular morphology of bulls in a tropical environment. Vet. Rec. 108, 13-15.

Majic., Balica S., Milinkovic, Turb M., Samardžijab S. and Vinceb. (2012) Effect of age and environmental factors on semen quality, glutathione peroxidase activity and oxidative parameters in simmental bulls. Theriogenology 78; 423-431.

Mathevon, M., Buhr, M.M. and Dekkers, J.C.M. (1998). Environmental, management and genetic factors affecting semen production in Holstein bulls. $J$. Dairy Sci. 81, 3321-3330.

Meyerhoeffer, D.C., Weffermann, R.P., Wells, M.E. and Turman, E.J. 1976. Effect of elevated ambient temperature on bulls. $J$. Anim. Sci. 43: 297

Mishra, S.R., Kundu, A.K. and Mahapatra, A.P.K. (2013). Effect of ambient temperature on membrane integrity of spermatozoa in different breeds of bulls. The bioscan. 8 (1): 181-183.

Moghdum, G. A., Pourseif, M. M. and Rafat, S. A. (2012). Seasonal variation in semen quantity and quality traits of iranian crossbred rams. XXVII World Buiatrics Congress 2012. Lisbon, Portugal.

Nagarcenkar, R. 1882. Breeding for dairy Production in the tropics. In 2nd world congress on Genetics applied to livestock production. National Dairy Research Institute, Karnal, India.

Nichi, M., Bols P. E., Züge, R. M., Barnabe V. H., Goovaerts I. G. and Barnabe R. C. (2006) Seasonal variation in semen quality in Bos indicus and Bos taurus 
bulls raised under tropical conditions. Theriogenology; 66:822-8.

Parkinson, T.J. 1987. Seasonal variations in semen quality of bulls: Correlation's with environmental temperature. The Vet. Record 120: 479-442

Pineda M. H. (2003). Male reproductive system. In: Pineda MH, Dooley MP, editors. Mc Donalds veterinary endocrinology and reproduction. Iowa: Iowa State Press; p. 239-82.

Rekwot, P.I., Voh Jr., A.A., Oyedipe, E.O., Opaluwa, G.I., Sekoni, V.O. and Dawuda, P.M. (1987). Influence of season on characteristics of the ejaculate from bulls in an artificial insemination center in Nigeria. Anim. Reprod. Sci. 14, 187-194.

Richthoff, J., Rylander, L., Hagmar, L. and Giwercman, A. (2003). Effect of cigarette smoking on reproductive characteristics in an unselected population of young males. Reprod. Biomed. Online., 7 (1): 8 9.

Roussel, J.D., Patrick, T.E., Kellgren, H.C. and Breidenstein, C.P. (1963). Effect of Artificial Light, Temperature, and Humidity on Physiological Response of Dairy Bulls. Journal of Dairy Science. Volume 46, Issue 10, October, Pages 1125-1131

Saacke, R. G. (1970). Morphology of sperm and its relationship to the fertility. Proc, $3^{\text {rd }}$. tech. Conf. A. I. Reprod. P: 17-30.

Salah, M. S., El-Nouty, F. D., Al-Hajri, M. R. and Mogawer, H. H. (1992). Effect of season on seminal characteristics of Holstein bull under semi- arid environment. Biophysical characteristics. AJAS. Vol. 5 (no. 3) 439- 447.

Schwab, W., Kupferschmied, H. \& Bachmann, P. 1987. Factors affecting semen production bulls. Zuchthygiene. 22: 241246.

Sekoni, V.O and Gustafsson, B.K. 1987. Seasonal variation in the incidence of sperm morphological abnormalities in dairy bulls regularly used for artificial insemination. Br. Vet. J. 143: 312-317.

Simson, S., Sohan, V. S., and Amit, K. (2016). Influence of Season on Semen Quality in Karan Fries (Tharparkar $\times$ Holstein Friesian) Bulls. Journal of Animal Research: v.6 n.2, p. 121-125.

Soderquist, L., Janson, L., Haard, M. and Einarsson, S. (1996). Influence of season, age, breed and some other factors on the variation in sperm morphological abnormalities in Swedish dairy AI bulls. Anim. Reprod. Sci. 44, 91-98.

Soderquist, L., Rodriguez-Martinez, H., Haard, M.G.H. and Lundeheim, N. (1997). Seasonal variation in sperm morphology in proven Swedish dairy AI bulls. Reprod. Dom. Anim. 32, 263-265.

Taylor, J.F., Bean, B., Marshall, C.E. and Sullivan, J.J. (1985). Genetic and environmental components of semen production traits of artificial insemination Holstein bulls. J. Dairy Sci. 68, 27032722.

Tomar, N.S., Misra, B.S. \& Johari, C.B. 1966. Seasonal variations in reaction time and semen production and prediction of some semen attributes on initial motility of spermatozoa in Hariana and Murrah bulls. Indian J. Dairy Sci. 19: 87-93.

Wildeus, S. and Hammond, A.C. (1993). Testicular, semen and blood parameters in adapted and non-adapted Bos taurus bulls in the semi-arid tropics. Theriogenology 40, 345-355.

\section{How to cite this article:}

Mridula Sharma, Bhat Yaqoob, Anoop Singh, Nishant Sharma and Shriya Rawat. 2017. Effect of Temperature Humidity Index on Semen Quality of Bovine Bull. Int.J.Curr.Microbiol.App.Sci. 6(12): 1822-1830. doi: https://doi.org/10.20546/ijcmas.2017.612.206 